\title{
Factors Affecting Mastitis Cases and the Correlations of Somatic Cell Count with Milk Production in Holstein Cows
}

\author{
Savaş Atasever ${ }^{1, a, *}$, Violetta Tóth ${ }^{2, b}$, Edit Mikón $^{2, c}$ \\ ${ }^{1}$ Department of Animal Science, Faculty of Agriculture, University of Ondokuz Mayis, 55139 Samsun, Turkey \\ ${ }^{2}$ Institute of Animal Sciences and Wildlife Management, Faculty of Agriculture, University of Szeged, 6800 Szeged, Hungary \\ *Corresponding author
}

\begin{tabular}{|c|c|}
\hline A R T I C L E I N F O & A B S T R A C T \\
\hline $\begin{array}{l}\text { Received : 05/09/2019 } \\
\text { Accepted : 17/12/2019 }\end{array}$ & $\begin{array}{l}\text { The aim of this study was to determine the factors affecting mastitis cases and to estimate the } \\
\text { correlations of somatic cell count (SCC) with milk yield in Holstein cows. The study was conducted } \\
\text { in two private dairy farms in Hódmezóvásárhely, South-Hungary. A total of } 882 \text { Holstein cows were } \\
\text { tested by SCC, fat and protein contents of milk monthly intervals. To test milk SCC and components, } \\
\text { two groups were designed, and to examine effect of parity on first mastitis day (FMD) and total } \\
\text { mastitis cases (TMC), four groups were divided. It was noted that higher SCC caused to higher TMC. } \\
\text { While cows had higher protein content exposed to higher FMD and TMC, cows had lower daily } \\
\text { milk yield (DMY) had higher values by mastitis case parameters. In parity evaluation, only } \\
\text { primiparous cows had statistically lower TMC. The cows with lower SCC were found in advance in } \\
\text { change of milk yield (CMY) up to } 6.858 \pm 0.947 \mathrm{~kg} \text {. A negative correlation coefficient was estimated } \\
\text { between SCC and DMY. Finally, monitoring SCC of milk is offered to prevent milk production } \\
\text { losses and new mastitis occurrences in the herds. }\end{array}$ \\
\hline
\end{tabular}

Milk yield

Somatic cell count

satasev@omu.edu.tr $\quad$ (i) https://orcid.org/0000-0002-0288-6197

\section{Introduction}

Mastitis is an important costly disease that affecting dairy herds all of the world. It is described by an infection of mammary gland and is classified to clinical and subclinical forms. The main adverse effects of this disease are reduction in milk yield and quality, increase in labor and cure costs. Atasever and Erdem (2008) reported that mastitis risk levels and milk production losses increase with advancing parity and lactation stage and also changing calving seasons. In mastitis control programs, some indirect markers those closely related with this case have been used. Of these, somatic cell count (SCC), which has a high genetic correlation with mastitis, is widely regarded in many countries. Somatic cells, which are mainly composed of macrophages, lymphocytes polymorph nuclear cells and some epithelial cells, are naturally present in milk. SCC increases when mastitis is characterized by inflammation due to bacterial infections in the udder gland (Kul et al., 2019). Somatic cells are secreted from milk as a normal process and are recorded for detecting mammary health or milk quality of dairy animals. However, SCC is firstly affected by intramammary infection, genotype of the cow, morphology of the udder, parity, stage of lactation, season, stress, herd size, milking interval, milking system, and milking management (Koc, 2015). SCC also affects the chemical components of milk. While SCC increases, the crude protein level of milk drops slowly (Litwinczuk et al., 2011), and an important reduction may be noted in lactose level (Barlowska et al., 2009). Jonas et al. (2016) reported a negative correlation between SCC and milk production level in dairy cows. In Turkey conditions, financial losses due to high SCC was estimated to be $\$ 217.8$ per milking cow (Atasever and Erdem, 2009).

Despite many studies have been carried out on mastitis case, information on the effective factors for mastitis occurrence time or total mastitis cases in a lactation are still needed. Also, emphasizing the change of milk yield by SCC and investigating the associations of SCC with milk production will ensure new sights to the dairy sector.

The aim of this study was to reveal the factors affecting mastitis cases and to estimate the correlations of SCC with milk yield in Hungarian Holstein cows. 


\section{Materials and Methods}

The study was conducted in two private dairy farms in Hódmezõvásárhely, South- Hungary. A total of 882 Holstein cows were chosen to be animal material. All cows were kept similar husbandry conditions by feeding and the other factors during the research. The cows were milked three times a day and the daily diets were formulated with a ration preparing program. The SCC and milk analyses were performed by monthly intervals. While SCC data were obtained by a milk analyser, fat and protein content (\%) of milk was analysed by spectrometer (Mikóné Jónás et al., 2018). To examine mastitis case, first mastitis day (FMD) of cows and total mastitis case (TMC) according to SCC results in the lactation was evaluated. To evaluate milk production level, daily milk yield (DMY) that recorded in the month when the cow exposed to mastitis were used. The means of fat and protein contents, and DMY were used as thresholds to design subgroups for these traits. SCC subgroups were designed using 400x10 cells $/ \mathrm{ml}$ value that reflects the highest limit of SCC of milk declared by EU directives (Yalcin and Atasever, 2018). To test effect of parity on mastitis case parameters, four groups were divided (cows with $\geq 4^{\text {th }}$ parity were assessed into the latest group). The SCC data were converted to $\log 10$ base ( $\log$ SCC) to ensure homogeneity of variance and a Pearson's correlation coefficient was estimated between $\log$ SCC and DMY. All statistical analyses were done using SPSS. 17 pocket program at the 0.05 significance level.

\section{Results and Discussion}

Non-genetic factors affecting FMD and TMC are presented in Table. While FMD means were not statistically significant by two SCC groups, it was determined significant $(\mathrm{P}<0.05)$ effects for TMC. At this point, it might be emphasized that higher SCC indicates to higher TMC. To prevent this condition, taking additional measures in the farms is seen as a logical approach.

Bruckmaier et al. (2004) emphasized that relatively high fat of content of milk is related to mastitis cases. In contrast, fat content of milk was not an effective factor for FMD and TMC in the present study. However, detailed investigations on this item should be carried out on different cow breeds to obtain more clear information.
Oppositely, significant differences $(\mathrm{P}<0.05)$ in FMD and TMC were found between two protein groups. As seen, cows with protein content of milk higher than the mean had exposed in a longer time by FMD. Also, these cows had more TMC when compared to those with higher protein in the milk. Really, milk protein is known to be an important component related to milk production and quality of milk. In this study, lower level of protein might be connected with early time and lower mastitis cases. Ogola et al. (2007) also reported low protein content of milk in cows with infected udder quarters.

Table 1 indicates that cows with lower yield were exposed to early and more mastitis cases. Indeed, high milk producing might be regarded to be an effective reason for entering mastitis in an early time (Jingar et al., 2014). However, finding on TMC in cows with lower yield was not found as harmonic with the initial result. At this point, taking great care in cows with high producing in the evaluated farms might be stated to be the possible reason of this scheme.

In the study, no significant effect of parity on FMD was determined, but TMC was lowest in cows with first parity. Basically, deformation of udder gland tissues with advanced parity might be seen to be the most important reason of this result. Similarly, report of Zhao and Lacasse (2008) clearly supports this mechanism.

In general evaluation, the mean of FMD was assumed to be moderate. Really, calculated mean here was assessed into a suitable stage that provides an opportunity for cows to combat mastitis in the retained lactation period. Besides, the mean of TMC of the examined cows was found as relatively high. In other words, taking additional precautions should be seen a first interfere to prevent high mastitis level in this herd.

To calculate the CMY according to SCC in milk, two subgroups were designed. As presented in Figure1, a significant difference $(\mathrm{P}<0.001)$ between the subgroups was found to be highly remarkable. Accordingly, cows with lower SCC had an advance in CMY up to $6.858 \pm 0.947$ $\mathrm{kg}$, however, cows in the second group exposed to milk losses CMY up to $1.112 \pm 0.822 \mathrm{~kg}$ when compared to previous DMY. This case clearly reflected that milk losses are closely related with high SCC. Really, findings of Juozaitiene et al. (2006) and Atasever and Erdem (2009) also supports this concept.

Table 1. Factors affecting mastitis cases

\begin{tabular}{l|ccrc}
\hline \multicolumn{1}{c|}{ Factors } & Thresholds & $\mathrm{n}$ & \multicolumn{1}{c}{ FMD } & TMC \\
\hline \multirow{2}{*}{ SCC (cells/ml) } & $<400 \times 10^{3}$ & 341 & $100.94 \pm 6.10$ & $2.60 \pm 0.10^{\mathrm{a}}$ \\
& $\geq 400 \times 10^{3}$ & 541 & $94.99 \pm 4.50$ & $3.99 \pm 0.11^{\mathrm{b}}$ \\
\hline \multirow{2}{*}{ Fat (\%) } & $\leq 3.94$ & 423 & $102.39 \pm 5.13$ & $3.58 \pm 0.12$ \\
& $>3.94$ & 459 & $92.59 \pm 5.13$ & $3.34 \pm 0.11$ \\
\hline \multirow{2}{*}{ Protein (\%) } & $\leq 3.28$ & 331 & $86.69 \pm 5.42^{\mathrm{a}}$ & $3.17 \pm 0.13^{\mathrm{a}}$ \\
& $>3.28$ & 551 & $103.66 \pm 4.80^{\mathrm{b}}$ & $3.63 \pm 0.11^{\mathrm{b}}$ \\
\hline \multirow{2}{*}{ DMY (kg) } & $\leq 27$ & 440 & $107.00 \pm 5.55^{\mathrm{b}}$ & $3.79 \pm 0.12^{\mathrm{b}}$ \\
& $>27$ & 441 & $87.46 \pm 4.66^{\mathrm{a}}$ & $3.13 \pm 0.11^{\mathrm{a}}$ \\
\hline \multirow{2}{*}{ Parity } & 1 & 283 & $94.47 \pm 6.79$ & $2.83 \pm 0.12^{\mathrm{a}}$ \\
& 2 & 294 & $105.11 \pm 6.22$ & $3.73 \pm 0.15^{\mathrm{b}}$ \\
\hline General & 3 & 190 & $92.67 \pm 7.24$ & $3.92 \pm 0.19^{\mathrm{b}}$ \\
\hline
\end{tabular}

Different superscript letters in the same column indicate statistically significant differences (P<0.05), FMD: first mastitis day; TMC: total mastitis case; SCC: somatic cell count; DMY: daily milk yield. 


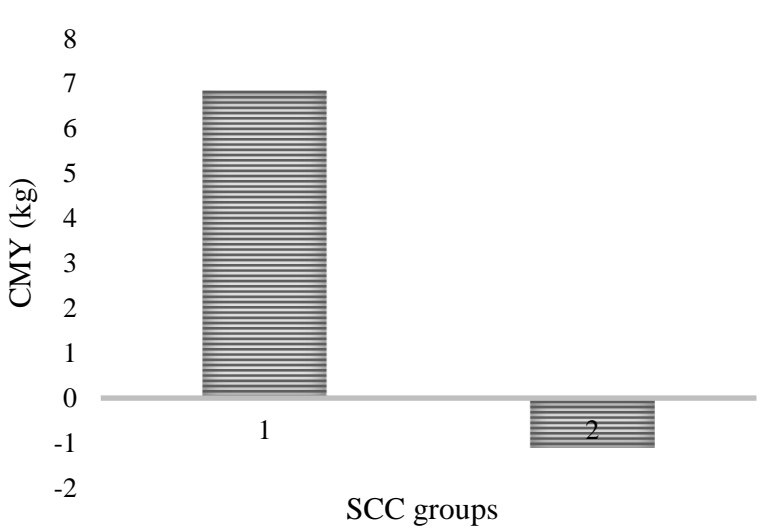

Figure 1. CMY levels (kg) by SCC subgroups (CMY: change of milk yield; SCC: somatic cell count; $1=<400 \times 10^{3}$ cells $/ \mathrm{ml} ; 2=\geq 400 \times 10^{3}$ cells $/ \mathrm{ml}$ )

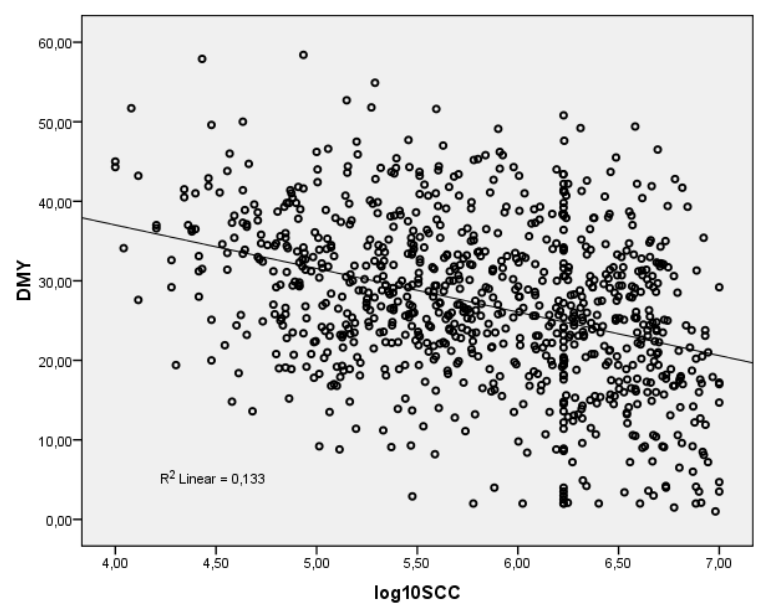

Figure 2. Correlations of $\operatorname{logSCC}$ with DMY

(logSCC: logarithmic somatic cell count; DMY: daily milk yield)

The correlations of $\log \mathrm{SCC}$ values with DMY is shown in Figure 2. A negative curve in the graphic and estimate negative correlation coefficient $(\mathrm{r}=-0.365)$ between two traits should be regarded as attractive notice. This finding was found to be harmonic with many study results (Juozaitiene et al., 2006; Atasever and Erdem, 2009; Koc, 2015) those determined earlier. To prevent milk production losses and also new mastitis occurrence rates in the herds, monitoring SCC of milk might be offered to be the main process on the herds.

\section{Conclusions}

In the present study, effective factors on mastitis and the asscociations of SCC with milk yield was investigated. It was revealed that FMD was affected by protein content and DMY, besides TMC was affected by SCC, protein content, DMY and parity. In this context, routinely tracking milk contents and SCC and keeping cows according to parity classes might be thought as the principal processes to control mastitis cases in dairy herds. Estimated negative correlation $(\mathrm{r}=-0.365)$ between SCC and milk production and also calculated milk losses caused by high SCC pointed out the importance of dropping SCC in milk to boost input of the farms.

Finally, monitoring SCC of milk within the acceptable thresholds was suggested to prevent milk losses and mastitis cases.

\section{References}

Atasever S, Erdem H. 2008. An Investigation on the determination of mastitis risk levels and milk production traits in Holstein cows. J. Appl. Anim. Res., 34: 13-16.

Atasever S, Erdem H. 2009. Estimation of milk yield and financial losses related to somatic cell count in Holstein cows raised in Turkey. J. Anim. Vet. Adv., 8(8): 1491-1494.

Barlowska J, Litwinczuk Z, Wolanciuk A, Brodziak A. 2009. Relationship of somatic cell count to daily yield and technological usefulness of milk from different breeds of cows. Pol. J. Vet. Sci., 12: 75-79.

Bruckmaier RM, Ontsouka CE, Blum JW. 2004. Fractionized milk composition in dairy cows with subclinical mastitis. Vet. Med., 49: 283-290.

Jingar SC, Mehla RK, Singh M, Singh PK. 2014. Effect of stages and level of milk production on mastitis incidence in cows and murrah buffaloes. J. Bio. Innov., 3:117-123.

Jonas EM, Atasever S, Graff M, Erdem H. 2016. Non-genetic factors affecting milk yield, composition and somatic cell count in Hungarian Holstein cows. Kafkas Univ. Vet. Fak. Derg., 22 (3): 361-366.

Juozaitiene V, Juozaitis A, Micikeviciene R. 2006. Relationship between somatic cell count and milk production or morphological traits of udder in Black-and-White cows. Turk. J. Vet. Anim. Sci., 30: 47-51.

Koc A. 2015. Effects of somatic cell count and various environmental factors on milk yield and foremilk constituents of Red-Holstein cows. J. Agric. Sci., 21: 439-447.

Kul E, Şahin A, Atasever S, Uğurlutepe E, Soydaner M. 2019. The effects of somatic cell count on milk yield and milk composition in Holstein cows. Vet. Arhiv., 89: 143-154.

Litwinczuk Z, Krol J, Brodziak A, Barlowska J. 2011. Changes of protein content and its fractions in bovine milk from different breeds subject to somatic cell count. J. Dairy Sci., 94: 684-691.

Mikóné Jónás E, Atasever S, Havranek E. 2018. Effect of premilking teat sanitation on milk composition, somatic cell count and test day milk yield in Holstein cows. Indian $\mathrm{J}$. Anim. Res., 52:1077-1081.

Ogola H, Shitandi A, Nanua J. 2007. Effect of mastitis on raw milk compositional quality. J. Vet. Sci., 8(3): 237-242.

Yalcin BK, Atasever S. 2018. Relationships between dye reduction test scores and somatic cell count in bovine raw milk. TURJAF, 6(5): 557-560.

Zhao X, Lacasse P. 2008. Mammary tissue damage during bovine mastitis: causes and control. J. Anim. Sci., 86 (13 Suppl.): 5765 . 